\title{
Role of Digital Marketing on Buying Behaviour of Youth
}

\section{K. Bhavani Selvi}

\begin{abstract}
This study was aimed to explore the customer perception towards various digital marketing practices followed by various e-commerce service providers in India. The researcher has adopted survey method with the help of questionnaire the primary data were collected from the youth who all are residing in Thiruvalluvar district of Tamil Nadu. The convenience sampling technique was adopted to collect the primary data from all the e-commerce and social media users in the study area. The result indicates that three factors such as, convenience, website design and time saving are the major factors influencing the customer perception towards digital marketing practices of various online service providers in India. Further, this study proves that safety and security measures in the online shopping websites need to be improved for the purpose of attracting and retain the customers over a period of time towards their website. To conclude, Online shoppers those who purchase the products and services via digital platform are suggested to spend some time to know about authenticity of information available in different platforms. The website should be attractive and well designed to capture the attention of the various customers to make their purchase decision.
\end{abstract}

Keywords: Digital Marketing, Online Shopping, Social Media and Youth buying behavior.

\section{INTRODUCTION}

Digital marketing is referred as reaching the prospective customers with the help of internet and various other online and digital platforms. The growth of digital technologies and boom in internet usage has greatly changed the behavior of every individual towards the social factors consideration. Purchase decision factors basically dynamic in nature due to the socio-cultural, technological and other factors influence (Shantharam et al., 2019). The factors such as, customer experience, brand, shopping comforts, price, place and product promotion are success factors in today's technological environment. The hyper competitive market and facilitates the various exposure to the customers for the purpose of indoctrination of customer purchase decision. $76 \%$ of total net commerce in India are contributed by online travel industry. Customers of online shopping are enchanted with flawless payment mechanisms and prompt delivery. The growth of online business, e-commerce and social media drastically changed the behavior of the buyer towards the purchase of various products and services. The innovation and creativity are the major factors helps the manufacturers and service providers to overcome many challenges such as, competition, weakness and other factors. This empirical study aims to explore various strategies adopted by the

Revised Manuscript Received on December 05, 2019.

* Correspondence Author

Dr. K. Bhavani Selvi*, Assistant Professor, Department of Commerce, DRBCCC Hindu College, Pattabiram, Chennai, India. customers before taking their purchase decision. There is a need to understand the digital marketing practices to device appropriate strategies to overcome barriers in business.

\section{A. Digital Marketing Scenario in India}

Indians are the third largest population of internet users and expected to reach second place at the end of 2020. The tremendous growth and increase for the use of digital marketing methods makes the marketing as a imperative concept to sell the products. The four components such as, product, price, place and promotion are major determinants of any product success. The role of digital marketing is to make the product as a successful one in their own market with the help and usage of various digital marketing techniques. The digital marketing makes every individual to take care of their own spending and purchase behavior without much influence of others due to the growth of technology and social media.

\section{REVIEW OF LITERATURE}

An attempt has been made to explore the existing review of literature for understanding the problem and approach towards digital marketing practices in the earlier studies. This helps the researcher to understand and explore the various aspects related to the present study. Balaji and Sreenivasa Murthy (2019) explored the role social media networking sites for creating awareness at the organisational environment to share the information effectively and efficiently. Further, the authors educated the importance and role of social media networking sites to increase the effectiveness in communication system. Chetanya Singh (2019) explored the effectiveness of digital marketing practices and initiatives in the banking industry with special reference to private bank in India. The result proves that digital marketing helps to increase the customer base and size of the beneficiaries. Further, the author concluded that e-mail marketing and content marketing are the innovative strategies to overcome the problems in the digital marketing. Soniya and Sudhamathi (2019) conducted a empirical study among women entrepreneurs perception towards the use of digital marketing strategies in their business. The result indicates that size of the investment and income are closely associated to each other and educational qualification of the women entrepreneurs are not the parameter to decide the digital marketing practices adoption in India. Nivetha and Sudhamathi (2019) studied the use of artificial intelligence in various aspects of marketing. The researchers stated that artificial intelligence helps to overcome the challenges and difficulties in the marketing. 


\section{STATEMENT OF THE PROBLEM}

In the growth of science and technology today's innovation becomes outdated tomorrow. Also there is a rapid change in the tastes and preferences of the consumers. It is finding difficult to the marketers to cope up with the changing need of the customers. Due to many reasons the expectations of the customers are changes, but one of the main reasons is changing buying behaviour. Buying behaviour changes are more seen among the youth than the younger children and old age people. The change in the buying behaviour of younger generation not only influences their individual buying behavior, but also it influences the buying behavior of their family. So the marketers are in need to understand the changing needs of the customers and to produce the goods and services according to their needs.

\section{NEED OF THE STUDY}

There are amazing changes in the way in which the marketer markets the product and the way in which the customers are buying the same through digital marketing. Buying behaviour of a customer influences many factors, and these factors perpetually affect the marketer to match with the needs of the customers in general and particularly youth. Hence, it is realized that there is a need to study "Digital Marketing and its impact on buying behavior of the youth".

\section{OBJECTIVES OF THE STUDY}

- To identify the role of digital marketing factors in determining the customer decision making.

- To understand the customer socio-economic conditions in Thiruvallur district of Tamil Nadu.

\section{RESEARCH METHODOLOGY}

The present study was empirical and exploratory and nature. Both primary and secondary data are application for this study. Primary data was collected from the youngsters residing in thiruvalluvar district of Tamil Nadu. The convenience sampling technique was adopted to gather the responses from the youngsters towards their perception on digital marketing practices followed by different set of companies. The final sample of 100 were finalized and subjected to data analysis using SPSS Version 23.0. The primary data was collected with the help of structured questionnaire designed for the same.

\section{DATA ANALYSIS AND DISCUSSION}

The primary data collected from 100 youngsters are subjected to likeret Test analysis by using simple percentage analysis. The result of the same were tabulated and presented in table 1.

Table - 1: Responses

\begin{tabular}{|l|c|c|c|c|c|c|c|}
\hline \multicolumn{1}{|c|}{ Variables } & $\begin{array}{c}\text { Strongly } \\
\text { Agree }\end{array}$ & $\begin{array}{c}\text { Agre } \\
\text { e }\end{array}$ & $\begin{array}{c}\text { Uncertai } \\
\text { n }\end{array}$ & $\begin{array}{c}\text { Disagre } \\
\text { e }\end{array}$ & $\begin{array}{c}\text { Strongly } \\
\text { Disagre } \\
\text { e }\end{array}$ & $\begin{array}{c}\text { Total } \\
\text { Weigh } \\
\text { t }\end{array}$ & $\begin{array}{c}\text { Ran } \\
\text { k }\end{array}$ \\
\hline Convenience & & & & & & & \\
\hline $\begin{array}{l}\text { I will get on-time delivery through } \\
\text { shopping on - line }\end{array}$ & $40(200)$ & $\begin{array}{c}25 \\
(100)\end{array}$ & $20(60)$ & $10(20)$ & $05(50)$ & 385 & I \\
\hline $\begin{array}{l}\text { Detail information is available about } \\
\text { the product while shopping online }\end{array}$ & $20(100)$ & $\begin{array}{c}25 \\
(100)\end{array}$ & $20(60)$ & $15(30)$ & $20(20)$ & 310 & IX \\
\hline $\begin{array}{l}\text { while shopping online It is easy to } \\
\text { compare the chosen product with other } \\
\text { product }\end{array}$ & $30(150)$ & $\begin{array}{c}25 \\
(100)\end{array}$ & $20(60)$ & $05(10)$ & $20(20)$ & 340 & IV \\
\hline $\begin{array}{l}\text { I can buy the product any time } \\
\text { throughout the day while shopping on } \\
\text { line }\end{array}$ & $32(160)$ & $\begin{array}{c}17 \\
(168)\end{array}$ & $18(54)$ & $16(32)$ & $17(17)$ & 331 & V \\
\hline Website Design & & & & & & & \\
\hline $\begin{array}{l}\text { The website design is very much } \\
\text { helpful to search product easily }\end{array}$ & $20(100)$ & $\begin{array}{c}10 \\
(40)\end{array}$ & $30(90)$ & $30(60)$ & $10(10)$ & 300 & X \\
\hline $\begin{array}{l}\text { While shopping online I prefer the } \\
\text { website that provides safety and ease of } \\
\text { routing and order a product }\end{array}$ & $15(75)$ & $\begin{array}{c}20 \\
(80)\end{array}$ & $25(75)$ & $24(48)$ & $16(16)$ & 294 & XII \\
\hline $\begin{array}{l}\text { The layout of the website helps me in } \\
\text { selecting the right product }\end{array}$ & $30(150)$ & $\begin{array}{c}25 \\
(100)\end{array}$ & $30(90)$ & $20(20)$ & $05(05)$ & 365 & III \\
\hline $\begin{array}{l}\text { Before actual purchase I believe that } \\
\text { the familiarity of the website will } \\
\text { reduce the risk of online purchase }\end{array}$ & $20(100)$ & $\begin{array}{c}15 \\
(60)\end{array}$ & $20(60)$ & $30(60)$ & $15(15)$ & 295 & XI \\
\hline $\begin{array}{l}\text { I prefer to buy from a website that } \\
\text { provides quality of information in all } \\
\text { aspects }\end{array}$ & $27(135)$ & $\begin{array}{c}22 \\
(84)\end{array}$ & $18(54)$ & $18(36)$ & $15(15)$ & 324 & VII \\
\hline Time Saving & & & & & \\
\hline
\end{tabular}




\begin{tabular}{|l|c|c|c|c|c|c|c|}
\hline $\begin{array}{l}\text { The purchase time is reduced in online } \\
\text { shopping }\end{array}$ & $35(175)$ & $\begin{array}{c}20 \\
(80)\end{array}$ & $30(90)$ & $10(20)$ & $05(05)$ & 370 & II \\
\hline Online shopping doesn't waste time & $25(125)$ & $\begin{array}{c}20 \\
(80)\end{array}$ & $15(45)$ & $25(50)$ & $15(15)$ & 315 & VIII \\
\hline $\begin{array}{l}\text { It takes less time in selecting and } \\
\text { evaluating the product through online }\end{array}$ & $29(145)$ & $\begin{array}{c}20 \\
(80)\end{array}$ & $18(54)$ & $18(36)$ & $15(15)$ & 330 & VI \\
\hline Security & & & & & & & \\
\hline $\begin{array}{l}\text { I sense it is safe and secure while } \\
\text { shopping online }\end{array}$ & $10(50)$ & $\begin{array}{c}20 \\
(80)\end{array}$ & $30(90)$ & $30(60)$ & $10(10)$ & 290 & XIII \\
\hline $\begin{array}{l}\text { My security is protected while online } \\
\text { shopping }\end{array}$ & $05(25)$ & $\begin{array}{c}10 \\
(40)\end{array}$ & $42(126)$ & $38(76)$ & $05(05)$ & 272 & XV \\
\hline $\begin{array}{l}\text { I like to shop online only from a } \\
\text { trustworthy website }\end{array}$ & $12(60)$ & $\begin{array}{c}20 \\
(80)\end{array}$ & $27(75)$ & $30(60)$ & $13(13)$ & 288 & XIV \\
\hline
\end{tabular}

Source: Primary Data

\section{FINDINGS OF THE STUDY}

The Likert scale analysis proves that convenience, website design and time saving factors are the major factors determining the online products purchase decision of individual customers in the study area. The customers are agreed that they receive the products within the stipulated time without much delay.

The various additional details are not available to customers those who prefers to use online or digital platform the purchase of products. The comparability of different available products with their own substitute products are helpful for the customers. Further, website design is very helpful for the customers to search for the products and layout of the website is also very attractive for the customers. The familiarity about the seller and reviews about products by previous users are very helpful to take their purchase decision. The safety and security measures taken by the online shopping facilitators are satisfactory among the respondents of this primary survey.

\section{SUGGESTIONS OF THE STUDY}

The online service providers are suggested to make necessary steps to create safety and security aspects satisfaction to their users since, they use various payment portal of many banks with lot of passwords and user details. So, they are suggested to make necessary steps to increase the safety features of the website. Online shoppers those who purchase the products and services via digital platform are suggested to spend some time to know about authenticity of information available in different platforms. The website should be attractive and well designed to capture the attention of the various customers to make their purchase decision. The e-commerce firms are suggested to provide seasonal discounts to their regular customer for the purpose of enhance the customer retention due to the hyper competitiveness in the market.

\section{CONCLUSION}

This empirical investigation proves that digital marketing strategies plays vital role in inducement of the customer decision making at various levels and movement of purchase in the e-commerce and online business. This study concludes that service providers should give appropriate and reliable information in their websites to make customers very attentive, aware and intelligent to take their purchase decisions. Further, they also suggested to use social media platform with the help of machine learning technologies to retain the existing customers as well as to attract the new customers.

\section{REFERENCES}

1. Balaji P, Sreenivasa Murthy S. (2019).Web 2.0: An Evaluation of Social Media Networking Sites. International Journal of Innovative Technology $\begin{array}{lll}\text { and Exploring } & \text { Engineering, } & \text { 752-759. }\end{array}$ doi:10.35940/ijitee.j8892.0881019.

2. Chetanya Singh. (2019). Effectiveness of Digital Marketing Initiatives in Improving the Performance of Banks with Special Reference to HDFC Bank. International Journal of Recent Technology and Engineering, 8 (4), 390-394. DOI:10.35940/ijrte.D6948.118419.

3. Nivetha. P, Sudhamathi. S. (2019). Marketing Trends using Latest Technology. (2019). International Journal of Recent Technology and Engineering, 8(2S6), 700-703. doi:10.35940/ijrte.b1132.0782s619.

4. Shantharam B. B, P. Balaji and Dr. P. Jagadeesan, Impact of Customer Commitment in Social Media Marketing on Purchase Decision - an Empirical Examination, International Journal of Management, 10 (2), 2019, pp. 320-326.

5. Soniya. S, Sudhamathi. S. (2019). Digital Marketing of Women Fashion Products towards Entrepreneurs Perspective in Chennai City. International Journal of Recent Technology and Engineering, 8(4), 11141-11146. doi:10.35940/ijrte.c5663.118419.

\section{AUTHOR PROFILE}

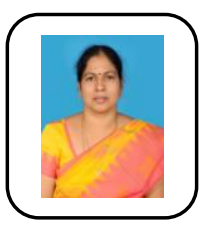

Dr. K. Bhavani Selvi, M.Com., M.Phil., Ph.D., Assistant Professor, Department of Commerce, DRBCCC Hindu College (Shift - 1), Pattabiram, Chennai - 600072 . Have Nineteen years of teaching experience to commerce students and participated, presented and published many articles in various national and international conferences across the Country. 